\title{
OCCUPATIONAL STATUS OF WOMEN AND FAMILY STABILITY IN GUINNESS NIGERIA PLC, LAGOS
}

\author{
Chiemeka, Onyema \\ $\mathrm{PhD}$, Department of Sociology \\ Imo State University, Owerri, Imo State, Nigeria
}

\author{
Iwu, Uchenna Okechukwu \\ Department of Sociology \\ Imo State University, Owerri, Imo State, \\ Nigeria
}

\begin{abstract}
This research investigated whether the occupational status of women has led to family stability in Nigeria. These days, women have refused to limit themselves within the confines of the home. Some of these women are now juggling between their home duties and their work roles which seems to have led to instability in the family.325 set of questionnaire were distributed while the researcher retrieved only 323 questionnaire. The questionnaire served as a source of primary data, while library research was source of secondary data. We adopted the survey research design for this study. The simple random and proportionate stratified sampling techniques were adopted. One hypothesis was formulated; it states that there is a significant relationship between women involvement in paid labour and attitude towards their husbands. Our hypothesis was tested using the chi-square statistical tool. We found that women's involvement in paid labour has positively affected their attitude towards their husbands. Based on the research finding, we recommend that: Women should be granted work flexibility in their various places of work so that they would be able to work and at the same time effectively care for the family. We also recommend that an enlightenment programme through the mass media should be organized in order to educate more members of the public on the importance of why women should be allowed to work outside the home.
\end{abstract}

Keywords - Occupation, Paid labour, Job demand, Substitutemother

\section{INTRODUCTION}

In traditional African societies, women are seen as the home keepers and makers. African women are usually assigned the domestic roles of cooking for the family, caring for the children, keeping the home clean, among other roles. African women also engage in farming at a subsistence level, and in trading. Traditional African women spend most of their time around the home, ensuring that nothing goes wrong in the home. In recent times, women are engaging in occupations that take them away from the home. Several factors have contributed to the trend and they include: complex social movements, equal opportunity legislation, the expansion of the service sector, the ever increasing cost of living, and the increased access to education has contributed to this change. Because of these factors, women have able to move from mainly supportive and nurturing roles to every sphere of occupational and professional life (Osuji, 2018).

The entry of women into the world of formal work has brought about the challenge of work-life balance for the women. The task and contextual situations in some workplaces have made it increasingly difficult for women to balance their work and family responsibilities in a satisfactory manner. Women now have to deal with issues such as low wages, long working hours, complex work environment, increased work demands, lack of gender-friendly workplace policies, and demands for over-time. These workplaces issues put women in difficult situations as they struggle to remain care-givers in the family as well as paid workers. The work demands often take the women to distant places, nationally and internationally (Ugwulebo, 2011), and because of this, the home suffers varying degrees of abandonment. The implication could be that she leaves her family in the hands of house- helps otherwise called maids who often lack the requisite home-making skills.

The reliance on house-helps as substitute mothers could affect the stability of the family. The absence of the woman from the home for long periods of time may cause disaffection between the husband and wife leading to estrangement, separation and divorce. These situations could arise when the maid constantly assumes and plays the role of 'substitute-mother' and the husband becomes increasingly attached to the maid. In some cases, the maid(s) transform into full blown wife, as co-wife with the globe-trotting madam, or even displace the madam and assume the status of the only wife. The impact of the real mother on the child(ren) could range from the adoption of wrong values to exhibiting anti-social behaviours such as becoming disrespectful, bullies, aggressive and being loathful.

There seems to be a tendency that when women change their status by getting involved in paid labour, they tend to subordinate their roles as mothers and care givers. This is often a precursor to friction within the family system. The women who adjust quickly may forestall marital crises and 


\section{International Journal of Engineering Applied Sciences and Technology, 2019 \\ Vol. 4, Issue 6, ISSN No. 2455-2143, Pages 344-348 \\ Published Online October 2019 in IJEAST (http://www.ijeast.com)}

achieve stability, while those who are unable or fail to adjust may experience marital instability. Some studies, for instance, Anyaoha and Onyema (2015) and Iwu (2019) stated that women's employment undoubtedly appears to create pressure for changes in the internal dynamics and organizations of family life. Women have made adjustments such as employment of house helps and nannies to help in home obligation due to their involvement in paid labour. They do less of the tasks traditionally thought as "women's work". For them, this process may not be without problem for the family. ... Therefore, this study investigated the effects of the changing occupational status of women on family stability in Nigeria, with Guinness Nigeria PLC (Public Liability Company) Lagos as focal point.

\section{OBJECTIVE OF THE STUDY}

The objective of this study is to investigate the effects of women's involvement in paid labour on their attitude towards their husbands

\section{HYPOTHESIS}

There is a significant relationship between women's involvement in paid labour and attitude towards their husbands.

\section{LITERATURE REVIEW AND THEORETICAL FRAMEWORK}

\section{Concept of occupational status}

Malachi (2016) sees occupation as any activity which people engage themselves for the purpose of earning money as salary or wage. Antingha (2015) argues that the occupational status of couples determines how the family will be adequately catered for. He is of the opinion that both of them (husband and wife) cannot be leaving the house, that one of them should consider staying back at home to cater and care for the family. Nwakanma (2017) asserts that there is a controversy regarding the meaning of occupational status, centering around the issue of whether status differences continues to entail difference entitlement. He further asserted that differential behaviour is still linked to occupational status differences, but as a result of the complexity of occupational systems in industrial societies, there have been changes in the settings in which display of difference occur. According to Mbachu (2017) Occupational status simply means the current situation one finds him or herself in terms of the type of occupation one is currently into.

\section{Changing occupational status of women}

Many scholars have made several contributions on the issue of changing occupational status of women. Adewale (2014), for instance argues that women's occupational status are gradually changing. For him, no woman wants to stay at home in the name of answering "house wives". Most women that have changed their occupational status did so in order to help their various families financially. Women all over the world especially in Nigeria are gradually changing their occupational status irrespective of the problems it might cause in their various homes. For a woman to move away from the home in search of paid labour simply means that other activities in her home may suffer. These activities include; care for the husband, care for the children, cooking and washing etc. if women are unable to balance their work life with their home activities, they might experience strain in their families.

Anugwom (2009) stated that until the late 1960's women were virtually not seen in the formal sector of the Nigerian economy. As a result, it was the atmosphere of general industrial development and urban growth that led to change in orientation towards women as people who could also be meaningfully used in the economic process of the society. Anugwom, went further to say that the involvement of women in formal employment was made possible through possession of skills and education by the women. Thus, until women in Nigeria became serious human resources with all manner of qualifications just like their male counterparts, they were not considered to be contributors to the economic system.

For Odunlade (2016), participation of women in the labour force has led to some changes in the family structure. Some women due to the fact that they earn more that their husbands tend to be disrespectful. This change has brought about family instability which might cause divorce. Ezeh (2018) argues that low paying traditionally female careers, including administrative support, sales, service, nursing, teaching, social work, and clerical jobs, reflected society's persistent attitudes regarding stereotypical occupational roles for males and female. This is because women's career choices were restricted, their earnings lagged behind their male counterparts with comparable education and experience. Income earnings have been found to increase with educational level and years employed. However, women earned roughly two-third the income of their male counterparts. This discrepancy in income was partially attributed to the disparity between traditionally male and traditionally female occupations. For example, women are less likely to be employed in science or engineering jobs, as these are considered traditionally male occupations.

Michael (2017) in the same vein, agrees that women are still the primary caregivers in the family, and that some workplace demands are set up in such a way that is incompatible with family needs. For him, women who have changed occupation will experience strain in combining employment and home keeping obligation. This is because the job of working outside is demanding and it exerts so much energy in mental calculation that women may not be in the right frame of mind to attend to home keeping obligation. Amauche (2017) argues that some women experienced feelings of guilt or selfishness if they put their career interests first. This is because women's work and family demands are simultaneously; these demands had a significant impact on women's careers. 


\section{International Journal of Engineering Applied Sciences and Technology, 2019 \\ Vol. 4, Issue 6, ISSN No. 2455-2143, Pages 344-348 \\ Published Online October 2019 in IJEAST (http://www.ijeast.com)}

Abayomi (2016) noted that women are seen as second class citizens particularly in Africa. Women are seen mainly as mothers and wives whose functions are to produce children, cook, and wash clothes. They care for their husbands and are subordinate to male authority. They are excluded from positions of power and high status occupation.

\section{Empirical Review}

Abel, Morrison and Tunde (2016), examined the effects of women's employment on family stability. The study was carried out at the University of Nigeria, Nsuka. It adopted the stratified sampling technique. The sample size was 300 respondents, questionnaire and interview was used in collecting data. The study revealed that money and salary are often reasons many women decide to move from one career to another. The study also reveals that 63 percent of women in paid labour consider a higher salary a reason to stay in a job or subsequently look for better opportunities.

Azubuike (2016) studied “impact of women's labour force participation on family stability" in Olabisi Onabanjo University, Ogun State, Nigeria. The study adopted the simple random sampling technique, the population of the study was 520 respondents, questionnaire was used in gathering data. The study found out that the expansion and increased access to education has increased women's opportunity to move from one job to another. The study also reveals that 60 percent of women in Nigeria has college degree which is gradually increasing the number of women in the workforce.

Festus (2015), examined the impact of women's employment on family instability in Friesland Nigeria Plc., Ogba Lagos. The study adopted the purposive sampling technique, the sample size of the study was 440 respondents, the study employed the questionnaire in collecting data, and the chisquare statistical tool was used in analyzing data collected from the field. The study revealed that when a woman changes her job, the children might suffer because she might not have the time to care for the children the way she used to. The study also revealed that the problem of women in paid labour is not money but the problem of managing a "ragged" family schedule and adjusting her role as mother. The study further revealed that women are currently juggling between full-time careers, managing house hold chores and child rearing as well as caring for husband, thus greatly increasing their level of daily stress compared to women of previous generations. The study also revealed that family relationship has also been shifting in dual-income families from patriarchal authority, fixed "role script" towards more flexible role negotiation and egalitarian relationships.

The rational choice theory was popularized by George Homans (1961). The rational choice theory is a framework for understanding social and economic behaviour. The basic premise of this theory is that aggregate social behavoiur results from behaviour of individual actors, each of whom is making their individual decisions. The theory also focuses on the determinants of individual choices. Rational choice theory then assumes that an individual has preferences among available choice alternatives that allow them to state which option they prefer.

Women, since their entry into the labour market, have it difficult to make a clear choice between their work and family obligations. Women who choose their work ahead of family obligations/ child care obligations may suffer instability in their various families. The choice a woman makes will make her lose either her paid work or her family, the inability of the woman to effectively make a choice that will help her balance her home duties with her office duties could lead to instability in the family.

\section{METHODOLOGY}

The research design for this work is the survey research design. Survey research design means the investigation of the opinion, behaviour or other manifestations of a group by questioning them. The researcher adopted the survey research design because of its flexibility to permit the use of a variety of data collection techniques. The population consists of women and men in Guinness Nigeria Plc., Lagos which is 650. The researcher chose a sample of 325 respondents through proportionate sampling. The respondents were drawn from 5 out of 9 departments in Guinness Nigeria Plc. Lagos. The departments were randomly selected.

Table 1: Departments and their Sample size Proportion

\begin{tabular}{|l|l|l|l|}
\hline Items & Departments & Branch & $\begin{array}{l}\text { No of } \\
\text { Staff }\end{array}$ \\
\hline 1 & Marketing and & Ikeja & 121 \\
\hline 2 & $\begin{array}{l}\text { Accounts } \\
\text { Finance }\end{array}$ & 74 \\
\hline 3 & Packaging & Ogba & 106 \\
\hline 4 & Quality Assurance & Ogba & 75 \\
\hline 5 & Health & Oba Akran (Ikeja) & 44 \\
\hline 6 & Insurance & Oba Akran(Ikeja) & 56 \\
\hline 7 & Engineering & Ogba & 41 \\
\hline 8 & $\begin{array}{l}\text { Research } \\
\text { Development }\end{array}$ & Ikeja & 60 \\
\hline 9 & Human Resources & Ikeja & 73 \\
\hline Total & & & 650 \\
\hline
\end{tabular}

Source (HR department of Guinness Nigeria Plc., Lagos)

The researcher adopted both the simple random sampling technique and proportionate sampling technique. In using the simple random sampling technique, the researcher adopted the hat-and-draw method, in using this method, the researcher wrote out the names of the 9 department in Guinness Nigeria, Lagos in pieces of paper, folded them, dropped them in a container, shuffles it, and picked blindfoldedly, the first five departments that made up the sample. Proportionate sampling technique was adopted because it enabled the researcher to distribute equal number of 
questionnaire to the respondents in each of the selected departments irrespective of their population. The researcher collected data using questionnaire and interview.

Data were presented using simple percentages and tables, while the hypotheses were tested using the Chi-Square statistical tool.

\section{RESULT AND DISCUSSION}

Table II: Distribution of questionnaire

\begin{tabular}{|l|l|l|l|l|}
\hline Departments & $\begin{array}{l}\text { Questionnair } \\
\text { e distributed }\end{array}$ & $\%$ & $\begin{array}{l}\text { Question } \\
\text { naire } \\
\text { returned }\end{array}$ & $\%$ \\
\hline Marketing & 65 & 20 & 65 & 20.1 \\
\hline $\begin{array}{l}\text { Accounts and } \\
\text { finance }\end{array}$ & 65 & 20 & 63 & 19.5 \\
\hline Packaging & 65 & 20 & 65 & 20.1 \\
\hline $\begin{array}{l}\text { Quality } \\
\text { assurance }\end{array}$ & 65 & 20 & 65 & 20.1 \\
\hline Health & 65 & 20 & 65 & 20.1 \\
\hline Total & 325 & 100 & 323 & 100 \\
\hline
\end{tabular}

$\%$ frequency distributed $=$ No of questionnaire distributed $\mathrm{x} 100$ Total questionnaire distributed

$\%$ frequency returned $=\underline{\text { No of questionnaire returned } \times 100}$ Total questionnaire returned

The above table shows that 325 set of questionnaire was distributed among the 5 selected departments in Guinness Nigeria Plc. Lagos. The researcher was able to retrieve 323 questionnaire which eventually forms the sample size for the study.

Table III women involvement in paid labour and their attitude towards their husbands

\begin{tabular}{|c|c|c|c|c|c|c|c|}
\hline & Questions & SA & $\mathrm{A}$ & SD & $\mathrm{D}$ & $\begin{array}{l}\text { Total } \\
\text { sample }\end{array}$ & $\%$ \\
\hline 1 & $\begin{array}{l}\text { Would you agree that women involvement in paid } \\
\text { labour has led to poor attitude towards their husband? }\end{array}$ & $\begin{array}{l}16 \\
(4.9)\end{array}$ & $\begin{array}{l}18 \\
(5.6)\end{array}$ & $\begin{array}{l}169 \\
(52.3)\end{array}$ & $\begin{array}{l}154 \\
(47.7)\end{array}$ & 323 & 100 \\
\hline 2 & $\begin{array}{l}\text { Would you agree that Women in paid labour } \\
\text { disrespects their husbands? }\end{array}$ & $\begin{array}{l}15 \\
(4.6)\end{array}$ & $\begin{array}{l}19 \\
5.9\end{array}$ & $\begin{array}{l}171 \\
52.9\end{array}$ & $\begin{array}{l}152 \\
47.0\end{array}$ & 323 & 100 \\
\hline 3 & $\begin{array}{l}\text { Would you agree that women's employment may } \\
\text { bring about misunderstanding among couples? }\end{array}$ & $\begin{array}{l}20 \\
6.2\end{array}$ & $\begin{array}{l}14 \\
4.3\end{array}$ & $\begin{array}{l}165 \\
51.1\end{array}$ & $\begin{array}{l}158 \\
48.9\end{array}$ & 323 & 100 \\
\hline 4 & $\begin{array}{l}\text { Would you agree that men deliberately allow their } \\
\text { wives to work so that the family burden that is on } \\
\text { them will reduce? }\end{array}$ & $\begin{array}{l}185 \\
57.3\end{array}$ & $\begin{array}{l}110 \\
34.0\end{array}$ & $\begin{array}{l}21 \\
6.5\end{array}$ & $\begin{array}{l}7 \\
2.2\end{array}$ & 323 & 100 \\
\hline 5 & $\begin{array}{l}\text { Would you agree that women deliberately engage in } \\
\text { paid labour so that they can gain more financial } \\
\text { power within and outside the family? }\end{array}$ & $\begin{array}{l}111 \\
34.4\end{array}$ & $\begin{array}{l}184 \\
57\end{array}$ & $\begin{array}{l}25 \\
7.7\end{array}$ & $\begin{array}{l}3 \\
0.9\end{array}$ & 323 & 100 \\
\hline
\end{tabular}

The above table shows that $64.4 \%$ of the respondents affirmed that women are gradually and deliberately changing their occupations, most of these women are moving into jobs that rewards them financially.

Table IV: Data for women involvement in paid labour and attitude towards their husbands

\begin{tabular}{|l|l|l|l|}
\hline $\mathrm{O}$ & $\mathrm{E}$ & $(\mathrm{O}-\mathrm{E})$ & $(\mathrm{O}-\mathrm{E})^{2 / \mathrm{E}}$ \\
\hline 221 & 73.7 & 147.7 & 3.9 \\
\hline 142 & 47.3 & 94.7 & 4.0 \\
\hline
\end{tabular}

\begin{tabular}{|l|l|l|l|}
\hline 355 & 118.3 & 236.7 & 3.9 \\
\hline 319 & 106.3 & 212.7 & 4.0 \\
\hline 221 & 73.7 & 147.3 & 3.9 \\
\hline 142 & 47.3 & 68.3 & 2.8 \\
\hline 355 & 118.3 & 33 & 0.5 \\
\hline 319 & 106.3 & 33 & 0.6 \\
\hline 221 & 77.3 & 9 & 0.2 \\
\hline 142 & 47.3 & 32.7 & 1.3 \\
\hline 355 & 118.3 & 22 & 0.3 \\
\hline
\end{tabular}




\begin{tabular}{|l|l|l|l|}
\hline 319 & 106.3 & 21 & 0.4 \\
\hline Total & & & 25.8 \\
\hline
\end{tabular}

The table value of $\mathrm{X}^{2}$ at a significance level of 0.05 and degree of $3=7.815$. The calculated value of $X^{2}=25.8$. Since the calculated value of $\mathrm{X}^{2}$ is greater than the table value of $\mathrm{X}^{2}$, we therefore accept the alternate hypothesis which states that there is a significant relationship between women involvement in paid labour and positive attitude towards their husbands.

\section{Discussion of findings}

Based on the research carried out on the changing occupational status of women and family stability in Guinness Nigeria Plc. Lagos, Nigeria, the researcher found out that;

Women's involvement in paid labour has positively affected their attitude towards their husbands. This is not in line with what Olubanji (2016) said that most women in paid labour, due to the fact that they earn more than their husbands, tends to disrespect their husbands which might threaten the stability of the home.

\section{CONCLUSION}

Based on the study conducted on the changing occupational status of women and family stability, we conclude that women involvement in paid labour has not made to start disrespecting their husbands rather, it has helped in increasing the respect they have for their husbands.

\section{REFERENCE}

1. Abayomi F.(2016). Gender Disparity in the Labour Force. Lagos : Alao Publishing Company Limited. (Pp.13-19)

2. Abel P., Morrison A., Tunde O. (2016). Why women change career in Nigeria. African Journal of Development. 5 (6)(pp.231-242).

3. Adewale M.A.(2014). Women and education in Nigeria. Journal of gender and education. 1 (1) (pp 82-86).

4. Amauche W.(2017). Africans and bias mentality against women. Journal of social science research. 6(3) (pp 80-88).

5. Antingha E. (2015). Women's educational status and involvement in paid labour. Journal of social science education. 4(4) (pp 17-20).

6. Anugwom E. (2009). Women and work in Nigeria. Educational research review.4(4) (pp127-134).

7. Azubuike A.(2016). Women's education and paid labour. Unpublished Msc Dissertation. University of Nigeria, Nsuka. (Pp.67-89)

8. Ezeh C. J.(2018).Women's job and marital obligation. Journal of Interpretive and scientific sociology. 6(5) (pp 7-11).
9. Festus $\mathrm{K}$.(2015).Women and labour force participation. Unpublished M.Sc thesis. Olabisi Onabanjo University. (Pp 23-45).

10. Jacobs C., and Jacobs., M.(2009). Occupational Status of Women in Africa. Warri: Akpobasa Publishers. (Pp 34-45)

11. Malachi C.U (2016).Women and work in Nigeria. Tunis: Abdumalik Publishers. (Pp 56-65).

12. Mbachu P. (2017). Emerging issues in women's occupational status.Lagos: Oguns publishing company. (Pp.18-28)

13. Michael C.(2017).Primitive women versus modern women in Africa. Owerri: Ihuoma printing press. (Pp36-43)

14. Nwakanma M.C.(2017). Occupation: The Nigeria context: Owerri: Achilike publishers. (Pp.39-44)

15. Odunlade C. (2016). Women's participation in the labour force. A Paper presented at the international conference of gender and paid labour in New York. (Pp.26-38).

\section{ACKNOWLEDGEMENTS}

We are greatful to Prof Emma Ugwulebo for his unreserved assistance during the course of this work. We also acknowledge all the authors that their works were cited in this research. 